\title{
New Dimensions in Sourcing and Utilization of Resource Materials for Effective Teaching and Instruction in Technical Vocational Education and Training (TVET) in Nigeria
}

\author{
Akpotohwo Festus Chukwunwendu* \\ Department of Vocational and Technology Education, Niger Delta University, Wilberforce Island, Bayelsa State, Nigeria \\ Email address: \\ festus.akpotohwo@mail.ndu.edu.ng (A. F. Chukwunwendu),drfestusakpotohwo@gmail.com (A. F. Chukwunwendu) \\ *Corresponding author
}

\section{To cite this article:}

Akpotohwo Festus Chukwunwendu. New Dimensions in Sourcing and Utilization of Resource Materials for Effective Teaching and Instruction in Technical Vocational Education and Training (TVET) in Nigeria. Education Journal. Special Issue: New Dimensions in Vocational Business Education Teaching and Learning. Vol. 4, No. 6-1, 2015, pp. 24-30. doi: 10.11648/j.edu.s.2015040601.15

Received: October 3, 2015; Accepted: October 7, 2015; Published: June 17, 2016

\begin{abstract}
The main purpose of technical vocational education and training TVET is to provide skilled manpower in applied science, engineering technology and commerce to operate, maintain and sustain the Nation's economic activities for rapid socio-economic development. TVET is a correlate to teaching practical skills. Because of the target audience of this type of education, it has become imperative to examine the new dimensions in instructional and training strategies from the perspectives of General Education and Training. In doing this, the paper focus on the following: TVET Path, Sourcing materials for instruction in TVET, Materials from Conventional Sources such as: print-based materials, video-based, Workshop/Laboratory, Sourcing from e-book materials through UNESCO-Nigeria TVET Project. It also looked at integrating ICT with TVET systems such as: Computer, networking and communication technology applications, Instructional materials/packages, Resource utilization for effective instructional delivery, Developing training assessment strategies and competency needs. The paper also took cognizance of the fact that teaching and instruction in each TVET course units has its prescribed resources to be utilized during instruction/teaching session and should be done using any of the appropriate multimedia gadgets in collaboration with industry linkages. The paper emphasized that the learning environment whether conventional classrooms or virtual should determine instructional materials sourcing and utilization and that Government should intensify effort in funding of TVET project by ensuring budget adequacy and funding to help develop TVET institutions. It recommends amongst others that: Promoters of UNESCO-Nigeria TVET Project should engage community and industry as significant players in TVET. It concludes that it is only when there is adequate funding that TVET Centers and Institutions can employ trained trainers, support them in updating and upgrading their skills, purchase most appropriate teaching facilities/materials, and instructional technology for practical on- the- job and handsactivities training.
\end{abstract}

Keywords: Sourcing, Utilization, Resource Materials, Technical, Vocational, Instructional Delivery

\section{Introduction}

TVET stand for technical vocational education and training. The main purpose of TVET is to provide skilled manpower in applied science, engineering technology and commerce to operate, maintain and sustain the Nation's economic activities for rapid socio-economic development.
TVET is designed to impart necessary skills and competencies leading to the production of Craftsmen, technicians and technologists, who will be enterprising and self-reliant, thus having the greatest potential to generate employment, reduce poverty and eliminate the 'Area Boys Syndrome' Federal Ministry of Education (FME, 2009). The Federal Ministry of Education further observed that the 
TVET objectives have by far not been realized due to the long period of systematic neglect and discrimination. However, because of the global clamour for technical and vocationalized economies, TVET has now assume a new National Anthem haven been given a renewed pep by UNESCO-Nigeria partnership.

\section{TVET Path}

At the basic education sector, technical and vocational education and training is infused into the subject areas with 35 entrepreneurial trade curriculum subjects. Schools are expected to ensure that adequate attentions are paid to enhancing the fundamental skills upon which TVET will be developed at the higher levels. Post Basic Education (PBE) is the education received after successful completion of nine years education and passing the Basic education Certificate Examination (BECE). PBE include: 3 - year Senior Secondary Examination (SSE), 3 - year Technical College, and Continuing Education provided in Vocational Enterprise Institutions (VEIs) to those who have successfully completed SSE but may not be proceeding to the tertiary level. Thus, TVET is seen as a project which permits the delivery of vocational education and training courses which allows school students to gain workplace skills and experience to get a head-start on their career (Technical and Further Education Commission, TAFE NSW, 2010). It allows recipients amongst other things, to start or complete a nationallyrecognized Technical Vocational Qualification Certification (TVQC) while still at school.

\section{What do we Study in TVET?}

There is a wide range of TVET courses offered across a variety of industry areas, such as multimedia technology and communications, children's services, beauty, tourism/hospitality, hairdressing, electrical/electronic, technicians, bricklaying, and more. Student can select an industry curriculum framework (ICF) course developed by the relevant agency or Board of Studies specifically for school students in a range of industry areas. Most countries that have adopted the TVET project currently house courses such as: Automotive, Business Services, Construction, Electro technology, Entertainment, Financial Services, Hospitality, Human Services, Information technology, Metal and Engineering, Primary Industries, Retailing, Tourism, Welding and fabrication etc.

\section{Sourcing Materials for Instruction in TVET}

TVET is a correlate to teaching practical skills. Because of the target audience of this type of education, it has become imperative to look at instructional and training strategies from the perspectives of General Education and Training. Acquisition of skills lends itself more to training which flows in the direction of instruction. Therefore, TVET is more instruction-based than in general education. This can be done most effectively in an organized school system in both conventional and virtual environment (i.e. the Open and Distance Learning - ODL, Joint Regional Program on Integrating ICT with TVET Systems (2008).

\section{Materials from Conventional Sources}

Sourcing from print-based materials: Under the TVET project, learners are provided with self-instructional materials (as a tutor-in-print/substitute for the teacher) to study at home on their own for those who by nature of their economic conditions may not be able to afford the conventional school system. During the face-to-face sessions that take place fortnightly at Special Learning Centres established in existing conventional technical and vocational institutions, the learners are also expected to get local personal support in the form of: tutorials, counseling, access to practical lessons, self-help study group activities, etc. The learning of theory is through print-based instructional materials.

Sourcing from video-based, Workshop/Laboratory: Regarding acquisition of practical skills, learners should initially use either print-based illustrations of step-by-step procedures or video-based practical lessons. In the case of the latter, the practical aspects of the course are converted into production scripts then shot, edited, and dubbed onto VCDs. The learners access the practical lessons using VCD players in their homes or at the learning centres. Practical skills acquisition is finally consolidated through hands-on-activities in the Workshops and Laboratories during face-to-face sessions at the learning centres under the supervision of an instructor/tutor.

Sourcing from e-book materials through UNESCO-Nigeria TVET Project: Efforts from Polytechnics in Nigerian under NBTE supervision in 2008 provided instructional materials for theory and practical courses under the UNESCO-Nigeria TVET Project-Phase II. The instructional materials in the form of e-books (now in CDs for 13 disciplines) for programmes covering: electrical/electronic technology, civil engineering technology, mechanical engineering technology, building technology, quantity surveying, computer technology, science laboratory technology, business administration accountancy, office technology and management, statistics, leisure and tourism management technology, and hospitality management. The instructional materials are based on the updated curriculum which is competency-based with emphasis on ICT, Entrepreneurship and hands-on-activities in the workshops and laboratories in line with the TVET vision.

\section{Integrating ICT with TVET Systems}

Sourcing and utilization of resource materials for TVET project has also been improved with the effort in 2008 of the Practical Initiative of the Joint Regional Program on 
Integrating ICT with TVET Systems in Manilla, Philippines. The rationale behind this initiative was hinged on the premise that Technological innovations have reached the classrooms and training centres bringing limitless opportunities to improve learning outcomes.

Computer, networking and communication technology applications: According to the Manilla program, there are many ways that computers are used in TVET institutions. The ICT applications based on the networking and communications technologies are becoming the fundamental tools for both administrative institutional management of teaching and learning methodologies on which planning, designing, implementation, and operation of TVET systems are being done. As a result, computers have become essential tools which could significantly aid in enhancing TVET students' learning skills.

Integrating World Wide Web (www) methods with TVET systems: Along with these advancements, the World Wide Web has become the emerging technology for education and training. The program noted that "anytime, anywhere, learning over the web" is now an essential facet for any educational institution. E-learning which is the idea of conducting learning and teaching over a network - is a fast, inexpensive and effective alternative to many comparable face-to-face educations. The availability of new technologies has made it easier to develop interactive resources for learning. In obtaining the integration of ICT into teaching learning process, all ICT frontline staff must understand how education technology can support pedagogy, thus resulting to better student performance (UNESCO-IBE, 2011). The importance of this media has motivated most countries to express interest in learning authoring technologies, multimedia and using web tools for building teaching and learning systems.

Utilizing Authoring Tools to create Multimedia Building Blocks included in the module are:

- Managing E-learning Project Life Cycles with Photoshop;

- Techniques in designing Graphic Interface with Photoshop;

- Introduction to Animation;

- Generating flash Animations for Training;

- Acknowledgement for TVET; why, What and How;

- Rapid E-learning development using Adobe Captivate.

Using web tool for delivery of Integrated Learning content module may include:

- Using web server for hosting E-learning;

- Integrating E-learning Building Block;

- Integrating ICT in Education;

- Designing effective blended learning through a pedagogical approach;

- Field visit (trip): This is a veritable aspect of instructional material sourcing which involves visitation to industry to experience live streaming of knowledge management and working out a synergy for life application of what have been learnt. The operations of Industrial Training Fund and the National Directorate of
Employment (NDE) Programmes have become useful methods for effective instructional delivery in TVET.

\section{Instructional Materials/Packages}

Instructional materials/package patterned towards the attainment of effective instructional delivery in TVET program can be described as a set of nationally endorsed qualifications, competency standards and assessment guidelines that describe the skills and knowledge needed to perform effectively in a particular industry or enterprise. Instructional materials/packages will enable the provision of:

- Nationally-recognized qualifications;

- Transportable qualifications;

- Nationally consistent training outcomes;

- Clear career pathways.

\section{Developing Instructional Packages}

The TVET policy requires that training packages should be developed by industry to meet industry training needs and should be overseen by a National Industry Skills Councils. Each training package is regularly reviewed with extensive consultation to ensure it meets industry's changing needs. And so, for education and particularly the TVET program to function as a total transformation of the learner, Nwosu (2012) advocates changes for quality education. This implies availability of instructional materials and improving classroom/virtual learning facilities by adopting quality information and communication technology (QICT) resources which has offered unlimited access to knowledge and information on skill acquisition. QICT refers to interactive communication tools that are useful for the transformation of learner and all people involved in the instruction and training process (Ibe-Bassey, 2011). They are critical tools that can be used in preparing and educating students with the required skills.

Identifying QICT teaching media: Iyamu and Ogiegbaen, (2010) following the reasoning of Chapin and Messick, distinguished between interactive and non-interactive QICT. Non-interactive QICT are media like: Films; Filmstrips; Television, Radio, video cassette. This category of QICT promotes passive learning. While Interactive QICT is media like: Computers, and Telecommunication gadgets. This category of QICT has the potentials to provide higher interaction for users to develop their intellectual and creative skill abilities and value re-orientation compared with noninteractive media. Studies have shown the unquantifiable benefits of the use of these QICT media both in the ODL classroom, workshops, laboratories and virtual learning environments. More difficult concepts are explained better through the QICT than through traditional teaching resources. This thereby enhances the effectiveness of information presentation and help stimulates learners' interests in improving their outcomes and quality TVET.

Available information indicates that the TVET coordinator 
and collaborating body have made effort to fund the review of all training packages and make modifications on competency standards to accurately reflect industry requirements. From 2001, these modifications are being progressively released in phases and steps.

\section{Resource Utilization for Effective Instructional Delivery}

Adequate hand-on-experience to all the learners is the primary instructional strategy in TVET courses. Most of the teaching/instruction sessions in the ICT environment are done with computer sessions with supporting presentations/demonstrations. The presentations are interactive in nature and the learners are expected to actively participate in the discussions and learning by doing. All learners are expected to be provided with computers and the learning activities should involve:

- Interactive theme presentations;

- Experience sharing through learners' presentations;

- Field visits to industry and institutions;

- Seminar presentations;

- Hands-on-practices by learners following instruction and demonstration by the tutor/trainer;

- Project work based on practical display of skills.

Conventional environment of instruction: The teaching of practical skills in TVET therefore requires the use of precise instructions to enable learners to follow the process and thereafter repeat the skill, whether within a conventional educational institution or via distance learning arrangement. Ward (2008) noted that in a typical conventional classroombased educational institution, an instructor provides such instructions in Workshops and Laboratories using the appropriate materials and equipment as can be accessed in the modular curriculum of instruction for the different TVET courses in the Programme-based institutions (in this case, the Polytechnic system as supervised by NBTE).

\section{Virtual (ODL) Environment of Instruction}

In the case of Open and Distance Learners who are separated from the instructor much of the time, the most frequently used method for teaching practical skills is the use of Print-based illustrations of step-by-step procedures (Donkor, 2010). This approach has its drawbacks and therefore, most recently, alternatives have been sought. One such alternative used by the President's Special Initiative on Distance Learning in the delivery of Block-laying and Concreting via distance learning in Ghana is Video-based practical lessons.

The virtual classroom which is an alternative and supplement to conventional classroom is an online teaching and learning environment that utilizes the potentials of: audio, video, text chat, application display, polling interactive to allow users to stimulate traditional instruction in online mode
(Michele, Emily and Martin, 2010). Using virtual instructional environment will enable the instructor or tutor to present lessons through: Video, PowerPoint or Charting. The learners are able to engage in collaborative learning, sharing experiences and creative activities.

\section{Examples of Resource Sourcing and Utilization}

The use of Computer and Video in the delivery of practical lessons is acknowledged in this discussion as veritable avenues for effective utilization of resource materials in TVET irrespective of the teaching/learning environment. For example, resource materials and teaching/instruction approaches in three trade areas of:- Animal Health \& Production Technology, Office Technology and Management, and Welding and Fabrication include the following:

Animal Health \& Production Technology: Apart from using Printed-Text materials, teacher/instructors activities would be to explain and demonstrate, illustrate and identify a Model of given animal showing the various parts listed. Resources in this case would be the use of "Models of animals" or "Animal Models" prepared histology slides showing different types of tissues e.g. Muscular, nervous connective etc, prepared slides, microscope, pictures, charts, drawings of various muscles of different animals, full mounted skeleton, mounted and preserved specimen of the hoof and foot of different animals, physiological wall charts and drawing of the various types of the digestive systems in different animals, maps - for identifying and describing the agro-ecological zones of Nigeria, fencing materials such as tapes, nail, bar wires , wood, nail, hoes, cutlass, tractors ploughs and harrowers, fertilizers, sickle, mower, forest harvester, drug samples etc.

Office Technology and Management (OTM): Apart from the use of Printed-Text materials, teacher/instructors activities would be to explain and demonstrate in the classroom/laboratory, the understanding and development of interest in Office related activities and functions by utilizing resources like: desks and visual aids, pictures, posters, diagrams of old equipment and new equipment, manual/electric typewriters, Personal Computers (PCs) and operating system running, computer workstation (including printers, scanners, adjustable chairs, etc), different types of keyboards, mice, monitors, floppy disks, CDs, workbooks, overhead projector, slides, video clips, mobile computers, organizational charts, chalkboard, whiteboard, flip chart, date stamping machines, stopwatch, shredding machine, delivery trolleys, staplers, punching, addressing, scaling machines, stamps, specimen papers (typing sheets) of different sizes, business directories, professional journals, Registry equipment, video equipment, etc. the instructors are therefore expected to demonstrate and supervise the use of all available types of office equipment and machines and take them on excursion to offices with different types of equipment by having frequent contacts with Registry in local 
organizations/businesses.

Welding and Fabrication: Apart from the use of reference Printed-Text materials, teacher/instructors activities would be to explain and demonstrate in a workshop/laboratory, the use of engineering materials and their properties, illustrate crystalline imperfection by using resources like: sample of Engineering Materials (Plastics, Wood, Metal, Concrete, etc), Models of BCC, FCC and HCP structures, model of Crystalline Arrangement with defects, chalk/blackboard, pencil, drawing sheet, drawing board, ruler, tri-square, video films, extinguishers fuel, Heat sources, furnace, mild steel rods, magnifying glasses, carburizing, consumables and other relevant accessories, drawing, charts and welding equipment, sample of ores, sample of steel products, copper alloys, alloying elements, welding machine, jig, fixture and manipulator, field trip to local industries.

That above examples can best be utilized when these resources are organised in video recordings and PCs' software. Mba (2011), sees video as 'a successful medium because it links the audio and visual together to provide a multisensory experience for the learners'. Donkor, (2010) observed that video makes it possible for the learner to play, replay, pause and rewind to specific sections of the lesson and further contends that "because practice and rehearsal is so important in developing competency, video is particularly well placed". Iroriteraye-Adjekpovu, (2013) also noted that video resources are expensive to produce but are very useful where practical demonstrations of skills are required. However, Droste (2005) emphasized that cost-savings are expected from reuse of video resources. Oranu, (2001) while corroborating the view of Iroriteraye-Adjekpovu, emphasised that video is useful to show practical and real life activities and that video can be used to capture hazardous and costly experiments for presentation and for repeated use. $C P$ software becomes handy as it creates a personalized learning environment for the learner with the use of Computer Aided Instruction (CAI).

\section{Developing Training Assessment Strategies and Competency Needs}

To achieve the aim of utilizing instructional resources as mentioned above, there is the need to develop training and assessment strategies. A training and assessment strategy guides and structures the delivery and assessment arrangements of a TVET qualification. It is initially developed by a course team in consultation with industry when applying for Scope of Registration. In the case of TVET Australia, activities undertaken in the development of a training and assessment strategy include:

- Determining industry and client needs;

- Selection qualification/units of competency;

- Determining target group needs;

- Determining training delivery methods and schedule;

- Determining assessment strategies;

- Determining validation processes.
It is recommended that training, instructional delivery and assessment strategies should be validated at least once a year, and the processed to achieve this must be identified in the training and assessment strategy documents. Process for validating the preparation delivery strategies may include: (i) industry consultation, (ii) training assessment strategy reviews and (iii) student satisfaction surveys. While processes for validation assessment strategies may include: (i) industry consultation, (ii) structured validation of assessment tools, (iii) student satisfaction surveys, (iv) peer review and (v) team assessment.

\section{Assessment tools and resource development}

While it is often necessary to develop teaching and assessment tools and resources, a large range of resources have already been developed for a number of training packages. Some are free to use but others are available for purchase. For instance, a large proportion of resources developed for and by the Australian Vocation Training sector can be customized to our specific needs - however, we should be aware of and adhere to any copyright conditions of use. You may also be able to source materials through some practitioners' standardized networks and communities of practice in the following web addresses:

Learnline.cdu.edu.au/t41/index.html., www.ntis.gov.au, www.resourcegenerator.gov.au

www.atpl.net.au, www.flexiblelearning.net.au/toolbox, www.vetassess.com.au

http://www.aesharenet.com.au/, www.aspiretraining.com.au/

There are other sources like: the Checklist for developing Indigenous e-learning resources, and Pearson Education-VET Resource Finder.

Resources can also be developed by using the following information and templates:

- VET Unit Information Template and Exempler: These according to Darwin (2011) are available on the Staff Intranet and will help you to develop unit information documents. Unit information must be provided to each student prior to or at the beginning of a training/teaching session.

- CDU Study Guide and Reading Print-based Templates: This is an optical resource to develop printed guides to direct student learning.

- CDU PowerPoint Presentation Shells: Template to design effective presentations.

All activities discussed so far should be geared towards thorough assessments of employability skills of the beneficiaries. How then do we assess these skills in order to give a direction of the types of instructional resources that could be sourced and effectively utilized? That brings us to the next aspect of this discussion.

Incorporating and assessing employability skills: A recent report commissioned by the Technical and Further Education 
Commission (TAFE, 2010) has identified the following employability skills:

- Communication skills that contribute to productive and harmonious relations between employees and customers.

- Teamwork skills that contribute to productive working relationships and outcomes;

- Problem-solving skills that contribute to productive outcomes;

- Initiative and enterprise skills that contribute to innovative outcomes;

- Planning and organizing skills that contribute to longterm and short-term strategic planning;

- Self-management skills that contribute to employee satisfaction and growth;

- Learning skills that contribute to on-going improvement and expansion in employee and company operations and outcomes; and

- Technology skills that contribute to effective execution of tasks.

Employability skills which remain the hallmark of TVET project represent an opportunity to improve training and assessment approaches and TVET practitioners should have flexibility in how competency standards are used to meet the employability skills needs of industry and learners when sourcing and making good use of resource materials for effective instructional delivery.

\section{Summary and Conclusion}

The instructional materials that have been emphasized in this discussion are hinged on the integration of the interactive and non-interactive QICT media like: Films; Filmstrips; Television, Radio, Video cassettes, Computers, and Telecommunication gadgets which fall in the category of QICT that promotes passive and interactive learning. We also took cognizance of the fact that teaching and instruction in each TVET course units has its prescribed resources to be utilized during instruction/teaching session and should be done using any of the appropriate multimedia gadgets in collaboration with industry linkages. The learning environment whether conventional classrooms or virtual should determine instructional materials sourcing and utilization.

On a final note, an effective planning, management and utilization of teaching and instructional resources depend now to a large extent on access to accurate information. Therefore, timeliness in the provision of education and resource management information systems is essential to achieving the objectives of effective teaching/instruction in TVET.

\section{Way Forward}

If it is our belief that the TVET project will work in Nigeria just as it is already yielding fruits in most countries in Africa and Asia, certain steps must be taken to improve resource availability for effective instruction and teaching. To this end, it is recommended that:

- Promoters of UNESCO-Nigeria TVET Project should engage community and industry as significant players in TVET.

- More workshops and other enlightenment programmes should be organized by the TVET coordinating body to redirect peoples' poor perceptions and mindset that vocational education is second choice to academic education while continuous review of our curriculum requirements for TVET courses and programmes should be vigorously encouraged.

- Government should intensify effort in funding of TVET project by ensuring budget adequacy and funding to help develop TVET institutions. It is only when there is adequate funding that TVET Centers and Institutions can employ trained trainers, support them in updating and upgrading their skills, purchase most appropriate teaching facilities/materials, and instructional technology for practical on- the- job and handsactivities training.

- There should be Policy and Legislative adequacies which will contribute to better performance of TVET in Nigeria. Therefore, the merger of Science and Technology into one Ministry should be reviewed to give TVET adequate attention.

- TVET trainers/educators should therefore be challenged to develop an accurate system of collecting, organizing and disseminating information to targeted users in accordance with their requirements.

\section{References}

[1] Darwin, C. (2011). Teaching for learning: A resource for academic staff. Darwin University: PVC Academic, OLT.

[2] Donkor, F. (2010). The comparative instructional effectiveness of print-based and video- based instructional materials for teaching practical skills at a distance. Online: www.irrodl.org/index.php/irridl/article/view/792/1486. University of Education, Winneba, Ghana.

[3] Droste, B. (2005). Why reinvent the wheel? VHS is already rolling the concord consortium. Online magazine http://concord.org/library/2000spring/reinvent.html.

[4] Federal Ministry of Education, (FME, 2009). Roadmap for the Nigerian education sector consultation draft. Access and Equity Technical and Vocational. Abuja: Federal Government Press.

[5] Ibe-Bassey, G. S. (2011). Human capacity building for information and communication technology (ICT) integration in teacher education in Nigeria. A Lead Paper presented at the 3rd international conference of Nigeria Association Educational Media and Technology (NAEMT).

[6] Iroriteraye-Adjekpovu, J. I. (2013). Quality information and communication technology (QICT) in the classroom: implication for virtual classroom for national values and development. Delsu Journal of Educational Research and Development - Special Edition. Faculty of Education, Delta State University, Abraka, Nigeria. 12(1), 108-115. 
[7] Iyamu, E. O. S. and Ogiegbaen, E. (2010). Assessment of the use of educational technology by social studies teachers in secondary schools in Western Nigeria. http//www.oscilite.org.au/ajet/e$\mathrm{jist} / \mathrm{docs} / \mathrm{vo} / 8 \mathrm{No} / \mathrm{commentary} / \mathrm{asses}$.

[8] Joint Regional Program on Integrating ICT with TVET Systems (2008). Inter-Governmental International Organization for Human Resources Development in Asia and the Pacific Region and Southeast Asian Ministers of Education Organisation Regional Centre for Vocational and Technical Education and Training. CPSC, Manila, Philipines.

[9] Kazaure, M. A. (2009). Revitalizing TVET in Nigeria. UNESCO's Section for Technical and Vocational Education, in cooperation with the National Board for Technical Education NBTE-UNESCO-Nigeria TVET Revitalization Project. Online at: www.unesco-Nigeriatve.org/PhaseII.html.

[10] Mba, I. (2011). Revamping our national economy through Technical Vocational Education and Training (TVET). Online at: www.nigerianbestforum.com/blog/revamping-our-nationaleconomy-through-technical-vocational-education-andtraining-tvet/

[11] Michele, A. A., Emily, R.G. and Martain (2010). Do you teach in a virtual classroom? : measuring students' perceptions of the features and characteristics. International Journal of Instructional Technology and Distance Learning 17(12), 34.
[12] Nwosu, F. C. (2012). Using educational computer game to foster quality and functional engineering education among Nigerian youths. Multidisciplinary Journal of Research Development 17(4), 112.

[13] Online www.tafensw.edu.au/courses/types.tvet.htm\#.uforGsu9ksn.

[14] Online: dabesaki.com/2012/03/12//revitalizing-tvet-in-nigeria/

[15] Oranu, R.N. (2001). Vocational and technical education in Nigeria. Geneva: UNESCO-IBE.

[16] Technical and Further Education Commission, (TAFE NSW, 2010).Not just a dream, Aboriginals students path way at TAFE NSW. Online: www.tafensw.edu.au/courses/types.tvet.htm\#.uforGsu9KSN. SNW

[17] UNESCO-IBE, (2011). World TVET Database VII ed. Nigeria. Geneva: UNESCO-IBE. Web-page of NBTE, accessed 16 July 2012.

[18] UNESCO UNEVOC: Integrating ICT with TVET Systems. Retrieved October, 16, 2009. From: http:/www2.ulcc.ac.uk/unesco/terms/list0.htm\#.

[19] Ward, J. (2008). Measuring student satisfaction with VET services... and getting it right! NCVER Research Report, June 2008. http://www.ncver.edu.au/publications/2008.html. 